\title{
The Arab Spring: A Game Changer in Turkey-EU Relations?
}

\section{O. Bahadır Dinçer \& Mustafa Kutlay}

To cite this article: O. Bahadır Dinçer \& Mustafa Kutlay (2013) The Arab Spring: A Game Changer in Turkey-EU Relations?, Perspectives on European Politics and Society, 14:4, 418-430, DOI: 10.1080/15705854.2012.753701

To link to this article: http://dx.doi.org/10.1080/15705854.2012.753701

册 Published online: 02 Feb 2013.

Submit your article to this journal $\pi$

Џll Article views: 1355

Q View related articles $\sqsubset$

4 Citing articles: 2 View citing articles 


\title{
The Arab Spring: A Game Changer in Turkey-EU Relations?
}

\author{
O. BAHADIR DINÇER* \& MUSTAFA KUTLAY ${ }^{\dagger}$ \\ *Bilkent University, Department of Political Science, Ankara, Turkey; research fellow at International \\ Strategic Research Organization (USAK), a Turkish think-tank, ${ }^{\dagger}$ Koc University, Department of \\ International Relations, Istanbul, Turkey
}

\begin{abstract}
We argue in this paper that the Arab Spring has opened a window of opportunity not just to create stability and democracy in one of the most unstable regions of the world, but also for revitalizing Turkey-EU relations. In theory, Turkey-EU cooperation can make a decisive difference in determining the outcome of the triangular relationship between stability, development, and democratization in the Arab region. In normative terms, as an opportunity, it must be turned into an advantage. From a practical perspective, however, transforming the window of opportunity into policy output is linked to the policy leadership of the sides involved to undergo a paradigm shift in their approach to the region and toward one another.
\end{abstract}

KeY Words: Arab Spring, democratization, revitalizing Turkey-EU relations, paradigm shift, policy leadership

\section{Introduction}

Mohamed Bouazizi, a university graduate street vendor, set fire to himself in Tunisia during the final days of 2010. Though he most probably did not realize it, Bouazizi had also lit the fuse for a wave of uprisings which drew millions of people into the streets. Not very long after the people of Tunisia had hoisted the flag of revolt, the country's dictator Zine El Abidine Ben Ali was forced to leave the country. Immediately afterward, President Hosni Mubarak who had ruled Egypt with an iron fist since 1981 was compelled to step down. The Egyptian people displayed historic solidarity, revolting against their country's dictator and achieving an unexpected success by overcoming the collective action problem. In subsequent waves, there were protest demonstrations in Libya and Syria which turned into bloodbaths, harbingers of a domino effect which would massively reshape the geopolitics of the Middle East. The hesitant first steps taken by the Tunisian people at the beginning of the uprisings evolved in the case of Syria into a determined stand which was undaunted despite all the bloody counter-measures against it. Although President Bashar al-Assad caused the deaths of

Correspondence Address: *Bilkent University, Department of Political Science, Ankara, Turkey. Email: obdincer@usak.org.tr Koç University, Department of International Relations, Istanbul, Turkey. Email: mkutlay@ku.edu.tr 
nearly 20,000 of his people, the Syrians transcended the wall of fear and set their country on a path from which there is no turning back. ${ }^{1}$

The popular uprisings in the Middle East and North Africa have been greeted with astonishment throughout the world. Many researchers, who have in the past addressed the question of why the ordinary people of this region were "so singularly resistant to democratization," (Bellin, 2004, p. 139) have found themselves trying to understand why the Arab people in the street were suddenly galvanized into action (see Bayat, 2010). Whatever its cause and no matter how consternation it created, the Arab awakening has triggered the slippage of a geopolitical tectonic plate, causing a fracture from which there can be no return to the status quo ante because a new period has opened. It is not just the relations between Arab regimes and their people which have been turned upside down, but also the strategies of global powers toward the region. In this matter, we have faced once more the unavoidable question in every political economy transformation: Who-gets-what in the Arab Spring? This study provides an answer to this perennial question along the lines of the TurkeyEU-Arab world triangle by arguing that Turkey's increased regional role and the combination of both the material and technical capacity of the EU along with the peoples of the region have the potential to influence the direction of the Arab Spring. It appears that with its growing proactivism and popularity, Turkey has become a source of inspiration for the people of the region. As some pundits assert, however, "Turkey seems to punch above its weight" (Abramowitz and Barkey, 2009, p. 1267). The EU, on the other hand, despite its technical and material capacity, has been hurt by a loss of legitimacy arising from securitized policies toward the Mediterranean region which exalted energy interests and the fight against illegal migration. The Turkey-EU nexus, therefore, could generate a non-zero-sum game in which the two sides complement each other's deficiencies and create the possibility for the Arab world to facilitate the transition to democracy. Yet for this to become a reality, the rules of the game in Turkey-EU relations need to be redefined.

We aim to provide an insider view by drawing upon wide-ranging discussions and interviews with Turkish and Arabic specialists on the subject and politicians involved in it. We also interviewed Western pundits to offer a balanced account. ${ }^{2}$ The first part examines the structural bases of the growing influence of Turkey in the Middle East and North Africa region over the last decade. Discussions of the Turkish model, in this context, are linked to historical and conceptual milieu. The second part deals with the evolution of the EU's policies toward the region in a critical perspective with special emphasis to the credibility of the EU in the eyes of Arab people. The third part reveals the complexity of the process in the Arab Spring and discusses the need of a paradigm shift in order to promote the Turkey-EU partnership to facilitate democratic transformation in the Arab lands. Hence the aim of this article is not to offer concrete cooperation mechanisms. Instead we aim to show that the parties need each other and the countries in the region may take advantage of Turkey-EU cooperation in their hard journey towards democracy.

\section{Turkey: A Rising, Yet Fledgling Regional Power}

There has been a good deal of discussion recently about how much Turkey is a source of inspiration for the Arab countries (Dede, 2011; Stone, 2011). Many 
Turkish opinion leaders argue that "Turkey's difference derives from it being, as it were, 'a black swan' [i.e. something which undermines arguments based on Islamdemocracy polarization]. " ${ }^{3}$ Accordingly, Turkey has won the applause of the people of the region to the extent that 73 per cent believes that "Turkey has become more influential in the Middle Eastern politics" and 66 per cent of them think that "Turkey can be a model for countries" in the Middle East, as TESEV survey reveals (Akgün et al., 2011, p. 12; see also Telhami, 2011). Furthermore, it is a political actor which has taken its relations with the Western world to the deepest levels as a member of NATO, a founding member of the Council of Europe, and a candidate country negotiating entry into the EU. In Sayyar Al-Jamil's words, "Turkey does provide a model of how to reconcile power in the military establishment with democracy and a secular system with a religious orientation. It also served as a model of economic success and a workable culture between East and West." ${ }^{\text {, It }}$ appears quasi-certain that the sympathy which Turkey has won among the people of many Arab countries is heavily affected by the charismatic leadership of its prime minister, Recep Tayyip Erdoğan, especially in the post-Davos period. ${ }^{5}$ We argue, however, that charismatic leadership and structural political economy dynamics combine to express a single meaning. We must therefore explore the fundamentals of Turkey's rising regional influence, which consist of (1) economic dynamism, (2) the institutionalized democracy and (3) soft power-driven proactive foreign policy.

The first pillar of Turkey's rising influence in the Middle East is driven by its economic transformation. In the years following 2001, Turkey introduced substantial economic reforms regarding the financial and public side of the economy (Öniş and Şenses, 2009). The financial system was overhauled comprehensively and a set of regulatory bodies made the Turkish banking system rise on solid foundations. In the last decade Turkey's GDP increased more than threefold and per capita income surpassed the $\$ 10,000$ threshold thanks to uninterrupted high growth performance.

In fact, the 2001 economic crisis, which is by far the biggest in Turkish economic history having shrunk the GDP by 7.4 per cent, implied that the end of the road had arrived for many banks accustomed to the rentier mode of capital accumulation strategies of the 1990s, and they were forced to stop extending "bad loans to good friends." In the post-crisis period, pro-integrationist strategies with a competitive outlook have become the only sustainable option for the Turkish business elite. In a parallel fashion, alternative economic interest groups, mainly the Anatolian Tigers

Table 1. Turkish Economy, Selected Indicators (2002-2010)

\begin{tabular}{lccccccccc}
\hline & 2002 & 2003 & 2004 & 2005 & 2006 & 2007 & 2008 & 2009 & 2010 \\
\hline GDP (US\$ Billions) & 232.7 & 304.6 & 393.0 & 484.0 & 529.9 & 655.9 & 742.1 & 617.6 & 735 \\
GDP Per Capita (US\$) & 3,403 & 4,393 & 5,595 & 6,801 & 7,351 & 8,984 & 10,745 & 8,950 & 10,067 \\
GDP Growth (\%) & 6.2 & 5.3 & 9.4 & 8.4 & 6.9 & 4.6 & 0.7 & -4.7 & 9 \\
Imports (US\$ Billions) & 51.5 & 69.3 & 97.5 & 116.8 & 139.6 & 170.1 & 201.0 & 140.9 & 185.5 \\
Exports (US\$ Billions) & 36.1 & 47.3 & 63.2 & 73.5 & 85.5 & 107.3 & 132.0 & 102.1 & 113.9 \\
FDI (US\$ Billions) & 1.08 & 1.75 & 2.79 & 10.03 & 20.19 & 22.05 & 18.27 & 7.66 & 9,3 \\
Fiscal Balance (\%GDP) & -11.47 & -8.84 & -5.22 & -1.06 & -0.61 & -1.62 & -1.97 & -4.88 & $-3,6$ \\
Total Public Debt & 61.4 & 55.1 & 49.0 & 41.6 & 34.0 & 29.5 & 28.2 & 32.5 & 42,2 \\
$\quad$ (\%GDP) & & & & & & & & & \\
\hline
\end{tabular}


that export heavily to Middle Eastern countries, have increased their gravity in Turkey's output which enabled them to make their voices heard in the decisionmaking echelons. During the last decade, the total volume of Turkish trade rose from $\$ 87.6$ billion in 2002 to more than $\$ 370$ billion in 2011. Concomitantly, Turkey's economic links with non-Western economies have expanded, notably with the markets of the Middle East and Central Asia. For example, the EU accounted for 55 per cent of Turkey's foreign trade in 2000 but at the end of 2010 the proportion had fallen to 40 per cent, whereas the share of Asia rose from 18 per cent to 30 per cent and that of the Middle East had gone up from 8 per cent to 15 per cent. The volume of Turkish trade with the Middle Eastern and Asian countries rose from $\$ 18$ billion to $\$ 131$ billion over the last ten years. ${ }^{6}$ In this context, the dynamism of the Anatolian Tigers, i.e. small and medium enterprises of the conservative Anatolian cities, has become the practical hand of Turkish foreign policy in ascertaining Turkey's regional power capability to solve the conflicts with its neighbours.

The second pillar of Turkey's rising influence in the Middle East is driven by its institutionalized democracy as a Muslim country. Though there are important defects of Turkish democracy, a point that will be addressed in the following pages, Turkey has succeeded in terms of establishing electoral democracy for more than half-century. The reform process which got underway following Turkey's acceptance as an EU candidate country in 1999 constitutes a turning point for Turkish democracy in several respects. In particular, reforms introduced between 1999 and 2006 produced vital advances in the liberalization and democratization of Turkey's political and legal structures (Öniş and Bakır, 2007). Turkey enacted two constitutional and nine legislative packages during an intense Europeanization period between 2002 and $2006 .{ }^{7}$ Reforms attributable to the process include, first and foremost, the abolition of the death penalty, and the right of citizens to publish in alternative dialects and languages, including Kurdish, which they traditionally used in daily life (Hale and Özbudun, 2010, p. 55-67). The EU accession process led to a changing balance in civil-military relations that is documented in amendments of the duties, functioning, and structure of the National Security Council, an increase in the civilian presence within it, and emphasis on the Council's consultative nature (Sarıil, 2007). Finally, a new perspective has emerged on the democratic opening, which aims to solve the deep-seated Kurdish problem in addition to the improvement of country-wide human rights standards. ${ }^{8}$ All these improvements consolidated Turkey's normative power in the eyes of many Arabs since Turkey has started to be seen as a pluralist society that proves Islam's compatibility with democracy. As al-Ahdab pinpoints;

The Turkish message stemming from a successful experience has an audience in the Arab world and amongst Islamist groups in particular. With such guidance the sterile current debate on whether democracy is compatible with Islam will be void. ${ }^{9}$

The third pillar on which Turkey's regional power capacity rests is its proactive foreign policy. The doctrine of "Strategic Depth" lying emphasis on more independent policy framework to "enable Ankara to enhance its freedom of action 
and increase its leverage, both regionally and globally" (Larrabee, 2010, p. 159) and the way in which Turkey has entered a process of political consolidation during the period the AKP has been in government, freeing the country from the previous unstable crisis-prone structures, have both made a positive contribution to Turkey's rising influence as a regional power in the Arab world. Accompanying economic dynamism and democratic consolidation, the third important catalyst is the transformation of the country's foreign policy identity, which may be described as a process of "de-elitization." As Aydinlı argued, the proactivism in Turkish foreign policy, if examined through the lens of identity transformation underway at the societal level, can be described as a practice of "re-elitization" following the initial "de-elitization" process. ${ }^{10}$ The entrepreneurial middle class has come to exert a relatively more influential position in decision-making mechanisms and thanks to an integrationist capital accumulation strategy backed by the government; Turkish entrepreneurs have penetrated Middle Eastern markets (Kutlay, 2011; Kirişci, Tocci and Walker, 2009, p. 21-2). The mutual interaction of all these transformations in the Turkish foreign policy identity produced a mentality of "engagement." This perception, in turn, has replaced the mentality of "threat" in Turkey's relations with its neighbours by positioning itself as a "benign regional power" (Öniş and Yılmaz, 2009). This new outlook perceives the Middle East "not as a bog from which one must keep one's distance but as a historical and cultural extension of Turkey that provides opportunities to take advantage on." 11 Therefore, Turkey's redefining of its historical and cultural ties with neighbouring countries along the axis of identity has opened the way to a change in perceptions of neighbours (Dinçer and Aydemir, 2011). In Davutoğlu's words, the new imaginative conception on which Turkish foreign policy is constructed relies on a multiple-identity definition which gives "priority to regional integration and cooperation in a mutually inclusive way in Western and Eastern worlds simultaneously."12

\section{The EU: A Wobbling, Yet Key Player}

Having witnessed the popular uprisings in the Arab world, it was not only the pundits who were caught unprepared but also many countries were taken aback by the developments. The EU heads the ranks of those caught politically unprepared. For a long time, despite arguments to the contrary, the EU's influence on countries in the Arab world has been rather limited. The limitations on its influence do not arise from any lack of appeal to the peoples of the region or because they see nothing in the Union to inspire them. The EU has produced several strategic plans and funnelled large amounts of funds into the Middle East. The Brussels' master plan toward the Mediterranean, the Barcelona Process, which was later subsumed into the European Neighbourhood Policy (hereinafter ENP), gave priority to economic liberalization and security matters. Although the ENP could not succeed in transforming the Mediterranean region into a free trade area in 2010, it did enable Brussels to make important material gains. For example, EU exports to countries included in the ENP rose 63 per cent between 2004 and 2008 and imports rose by 92 per cent. During the same period, total EU trade with the region rose above $€ 200$ billion (Grant, 2011, p. 4). This increase, however, did not produce the benefits for the people of the region that had been intended because in return for trade 
liberalization, the EU relied on authoritarian leaders and toned down its criticisms of oppressive rulers, and so economic liberalization in a way was hush money to prevent their legitimacy from being discussed. Therefore as economic interdependence increased, it was the rulers of the region rather than its peoples who prospered from it.

Our interviews revealed that in the eyes of many Arab pundits it is hard to claim, whatever may be officially stated, that the EU's approach to the Middle East was very different from that of the U.S. or that it led to any different outcome (see also Tocci and Cassarino, 2011). The degree of disappointment even dragged some Arab intellectuals to sensational rhetoric. For example, in al-Hafidh's words, "people in the Arab streets are neither pleased nor have confidence in the U.S. and EU. To them, there is a lot of hypocrisy in the policy of abandoning dictators in the last minute following years of endorsement, support and intelligence co-ordinations."13 In fact, it led to the tragic point where before the Tunisian dictator escaped to Saudi Arabia, the French foreign minister, Michèle Alliot-Marie, proposed dispatching French security forces to Ben Ali to prop up the ostracized Tunisian regime (Traynor and Willsher, 2011).

The second factor going beyond economic self-interest which impelled the EU member states to cooperate with the authoritarian regimes was the methods that they employed in the struggle against illegal immigration. It is far from debate that illegal immigration is a real threat to the socio-economic stability of the EU countries. The physiological climate created by the $9 / 11$ attacks, however, has consolidated a sceptic perspective as a result of which immigration has been seen solely from the securityoriented point of view, and the EU veered into the "securitization" of immigration policies (see Huysmans, 2000). Accordingly, EU leaders tended to compromise with, and even demonstrate tolerance toward, authoritarian leaders with whom they had managed to reach agreement on the subject of immigration and border security. This situation was neatly expressed in the words of Füle (2011), the EU Commissioner for Enlargement and Neighbourhood policy;

We must show humility about the past. Europe was not vocal enough in defending human rights and local democratic forces in the region. Too many of us fell prey to the assumption those authoritarian regimes were a guarantee of stability in the region. This was not even Realpolitik. It was, at best, short-termism and the kind of short-termism that makes the long term ever more difficult to build.

Table 2. The Poor Development Performance of Middle Eastern and North African Countries

\begin{tabular}{lccccccc}
\hline & $\begin{array}{c}\text { Human } \\
\text { Development } \\
\text { Index }\end{array}$ & $\begin{array}{c}\text { Population } \\
\text { Below } \\
\text { Age 25 }(\%)\end{array}$ & $\begin{array}{c}\text { Population } \\
\text { under } \\
\text { Poverty } \\
\text { Line }(\%)\end{array}$ & $\begin{array}{c}\text { Democracy } \\
\text { Ranking } \\
\text { (out of 167) }\end{array}$ & $\begin{array}{c}\text { Corruption } \\
\text { Ranking } \\
\text { (out of 178) }\end{array}$ & $\begin{array}{c}\text { Press } \\
\text { Freedom } \\
\text { Ranking } \\
\text { (out of 195) }\end{array}$ & $\begin{array}{c}\text { Unemployment } \\
\text { Rate } \\
(\%)\end{array}$ \\
\hline Tunisia & 0.698 & 42.3 & 3.8 & 144 & 59 & 186 & 14 \\
Egypt & 0.644 & 52.2 & 20 & 138 & 98 & 130 & 9.7 \\
Syria & 0.632 & 55.1 & 11.9 & 153 & 127 & 178 & 8.3 \\
Libya & 0.760 & 47.6 & 33 & 158 & 146 & 193 & 30 \\
Yemen & 0.462 & 65.4 & 45.2 & 146 & 146 & 173 & 35 \\
Algeria & 0.698 & 47.6 & 23 & 125 & 105 & 141 & 9.9 \\
\hline
\end{tabular}

Sources: UNDP-Human Development Report (2011), Economist Intelligence Unit (2010) 
Consequently, the one-sided initiatives of the EU were greeted with an unfavourable reaction from the peoples of the region and categorically rejected regardless of their real aims. Al-Ahdap expresses this by saying "Europeans don't know what we want and probably do not know how to deal with us." 14 Therefore, the EU's soft power arsenal seems rather limited in effecting transformations in the region. ${ }^{15}$ Not surprisingly, a point has been reached where we face the EU functioning well below its efficiency frontier in the region.

Despite all the deficiencies, if the EU were to thoroughly overhaul its policies toward this region, it would possess the potential needed to increase its effectiveness as an active agent of democratic transformation. The areas in which the EU possesses advantages are twofold. The first is Brussels' capacity for high-level human and capital mobilization, arising from its sophisticated institutional political economy structures. In the contemporary era, despite the euro zone crisis, the EU ranks as the largest economic bloc, trading power, and official development aid provider in the world. Under the European Neighbourhood and Partnership Instrument, for example, $€ 11.2$ billion has been set aside for the period between 2007 and 2013 (Tocci and Cassarino, 2011). It is expected that $€ 4$ billion of this funding will be utilized in the coming three years. In addition to these funds, the EU has access to further development funding in its associated bodies and has already gone into action to secure additional funding for the coming period. If used intelligently as part of a comprehensive strategy, its economic power would be sufficient to make the EU a centre of attraction for the people of the region. Second, the emphasis which the EU lays on multilateralism, mainly thanks to its own ontology, could produce an advantage in terms of enabling the peoples of the region to have a say in the decisiontaking processes via civil society channels and democratic participation. This would enable the EU to dispose of negative perceptions inherited from the past and bring its normative strength into play by allowing it to appear as a political actor which does not impose or dictate but one which listens and accompanies. ${ }^{16}$ In fact, it is only by breaking such a psychological threshold that the material instruments that the EU possesses can become useful as components of its transformational power in the region. We argue that it is this point which brings out the full importance of TurkishEU cooperation in the Arab Spring context.

\section{The Need for Turkey-EU Cooperation: Beyond Reluctant Equilibrium}

It is true that Turkey's historical baggage is quite loaded in the Middle East and Turkey has a Janus-faced character about exclusion and inclusion when it comes to its relations with Arab states. ${ }^{17}$ Nevertheless, especially over the last ten years, the Islamist-rooted conservative AKP improved Turkey's positive image in the Muslim world to a considerable extent. Indeed there are even some analysts in addition to our Arab interviewees who believe that in a way or another, to some degree it was Turkey, as a Muslim and democratic country, which inspired the Arab streets. ${ }^{18}$ Although we believe that this is an overly exaggerated claim, it has a point: Turkey is a country that proves that democracy and Islam are not mutually exclusive and as such is a trustworthy ally for the Arab peoples. Yet, Turkey is a medium-sized power and its capacity is rather limited. When it is compared to the potential which it has, with respect to the bases of normative power, the material instruments it possesses 
are inadequate to the extent that some scholars aptly label Turkey a country suffering from the lack of capacity. ${ }^{19}$ As a proxy indicator for diplomatic capacity, for example, Turkey has just 135 diplomatic staff in Arab countries in total and only 6 of them can speak Arabic. ${ }^{20}$

Furthermore, Turkey has domestic problems and despite the progress in the Kurdish question over the last couple of years, a failure in enacting a new inclusive constitution may swiftly deteriorate Turkey's soft power credentials in the eyes of Arab people. ${ }^{21}$ In this regard, Turkey like the EU is an actor with a deficit in the balance between its expectations and capacity. The synergy that cooperation between Turkey and the EU could create in the region springs precisely from this point. It is hard to believe that the EU could achieve a substantial transformation per se because of the negative image it currently has, while Turkey's room for manoeuvre is restricted by its limited capacity. If Turkey and the EU do act together, then it will be easier to boost their capacity and to integrate the countries which are going through transition into the democratic realm via healthy channels. In any bilateral mechanism to be set up by Turkey and the EU, if local elements from the region are included the legitimacy of the mechanisms will become stronger. It would mean that common problems and common solutions could be identified and most important of all, a road map could be drafted which would not appear to be something imposed on the region. Every political actor involved would be able to act on the basis of shared values. The common purpose must be the public declaration of the need to consolidate democracy and human rights, broaden freedoms, and accept a development and security strategy based on these values. Involving local participation from the region would open the way to proceed in a more fully aware fashion regarding the expectations and sensitivities of the Arabs. ${ }^{22}$ The further involvement of civil society organizations would create a trilateral mechanism able to overcome any sense that the potential for cooperation had been wrecked by some feeling that the transformation was being imposed from the outside. If this did not happen and if there was the perception that the changes were being imposed from the outside, this would not just damage the initiative we are proposing, it might even have a negative impact on the transformation process in the region.

\section{Policy Leadership in Hard Times}

The window of opportunity which opens the way for major transformations in the international system and the potential for cooperation, however, are not always translated directly into the building of relevant political structures. The existence of policy leadership able to seize opportunities is of vital importance for capitalizing on the potential in question. In other words, the paradigm shift which the system has made possible requires strategic intervention at the level of political actors to convert the opportunity into action. This state of affairs applies not just to what is happening in the Arab world but is also valid for the EU when it comes to its relations with Turkey. As Schubs argues "the relations between Turkey and the EU is in itself of paramount importance, and it would be regrettable to miss this historical opportunity." 23 Yet, a selective concentration on cooperation possibilities only within the context of the Arab world would be a partial equilibrium analysis. We offer to place Turkey-EU relations into a general equilibrium analysis context and 
proffer a paradigm shift for both sides to efficiently capitalize on the window of opportunity opened with the Arab Spring. For as things currently stand, there is no strategic vision to be discerned in the relations, but rather a tendency just to muddle through. The EU, deeply puzzled about how it should direct its relations with Turkey, allows some countries to take the lead in sending Ankara highly contradictory signals.

After the kick-off of formal negotiations in 2005, Turkey-EU relations have been running at low ebb because the relations have slacked to a point where they exist in name but without much substance, seemingly due to the Cyprus question. Since Turkey did not open its ports on the ground that the EU did not comply with its promises to lift the bans against the Turkish Cypriot community after the Annan referenda due to the Greek and Greek Cypriot vetoes, the European Council froze eight chapters and decided not to close others until Turkey opens its ports to Greek Cypriot vessels. In the following years, the negotiations further deteriorated since the former French president Sarkozy unilaterally blocked more negotiating chapters in addition to the Greek Cypriot veto on six others. German Prime Minister Merkel's die-hard stance against Turkey's membership was the final punch that pushed the relations into almost a deadlock. The post-2004 period depicted a crystal clear case of reluctant equilibrium between Turkey and the EU because Ankara aims to conclude the negotiations as soon as possible and wants to become a member of the EU, while the Paris-Berlin axis insists on an alternative "open-ended" relationship in lieu of the full membership prospect. Since neither of the parties is capable of distorting the existing balance in their favour due to various political economy reasons, the relations have plunged into a temporary cul-de-sac clearly depicting a sub-optimal balance (Ugur, 2010). Not surprisingly, as a result, "all these actions make Turkey lose faith in the EU and any hopes it has of becoming an EU member." 24 Turkey's counter-response to the EU's faltering policies has been a vision shift in terms of its traditional EU policies. The EU membership goal is no longer the top priority for Turkish policy-makers, and the Turkish foreign policy elite find the EU to be "too slow to cooperate at the institutional level.". Consequently, Turkey-EU relations are going through a thorough test of confidence.

\section{Bad Timing: Economic Crisis Knocks Europe's Door}

Beyond the negative impact of sticky ideas, one other crucial impediment to the EU's ability to assume a sufficiently proactive role in the Arab world is the deep economic crisis which it is currently weathering. The economic meltdown had an impact on the EU's policies toward the Arab Spring for three reasons. First, the crisis caused the EU to become more inward-prone both at the institutional level and as far as member countries were concerned. ${ }^{26}$

The countries of the EU were busy trying to put their own houses in order and so they could not divert their energy and resources into foreign relations and the Arab world. Second, the crisis had led to a financial contraction and belt-tightening measures which correspondingly reduced the EU's options in external relations (Frattini, 2011; Dadush and Dunne, 2011, p. 134). Even though the ENP has been restructured, the amount of financial assistance now being allocated to the region is "too little and too late" to have much impact (Rettman, 2011). Third, the countries 
of Southern Europe who believed that the EU should pursue an active policy toward the Mediterranean and North Africa and were making initiatives relating to it have been the worst-hit victims of the euro crisis. In a sense, the Arab Spring has become the Mediterranean Autumn.

In view of the wide-ranging structural problems which underlie the euro crisis, it is clear that the EU does not face an easy future. European integration is used to difficult times, but even if we make an optimistic forecast that it will somehow be reborn from the ashes of the euro crisis, it needs to be borne in mind that the time an economic recovery will take means important opportunities will be missed. The EU needs new markets, a young demography, and cooperation with dynamic economies. In this context, a recipe for a recovery may be the Middle East region of which Turkey is an integral part.

\section{Conclusion}

In the 1970s, the EU helped the democratization of Spain, Portugal, and Greece when they were in the hands of dictators and managed to establish its norms in this region, which in turn transformed the EU into a Mediterranean power becoming an active player in Middle East politics (Pinto and Teixeira, 2002; Royo and Manuel, 2003). After the Eastern European countries became independent, they enjoyed the fundamental advantage of having secured a European perspective for themselves during the transition process (Smith, 2005). The Arab Spring has opened a new window of opportunity to achieve a transformation in the Arab world comparable to that in Southern and Eastern Europe. The recent wave, however, diverges from the previous ones in a fundamental way in the sense that the EU does not provide membership prospect in the ENP context and EU's transformative power is deteriorated in cases where membership vision is not provided to the countries in question. Nevertheless, in the Arab Spring, Turkey's candidacy and active TurkeyEU cooperation may be substituted as an asset in fulfilling the missing link.

The Arab revolutions began through the dynamics of domestic cleavages, and their main participants have been the ordinary people of the Middle East who from now on will be the real architects of their countries' fates. If the EU were to take a central part in the process, however, one concerned not just with responsibilities but also with practical interests, this would make a much-needed contribution to ensuring that the historical transformation in the Arab world has a successful outcome in democratic consolidation. Doubtless the transformation in the Arab world will take many painful years to complete and the ultimate success of democratization, as Huntington (1991) underlines, depends on a complex web of factors. The recent wave also has a potential to trigger-back and the transitory regimes may plunge into another type of authoritarianism as well. Both Turkey and the EU, in the backyards of which this transformation is taking place, would benefit from supporting and making a long-term contribution to the democratization process in the region. After decades of research, we can confidently argue that there is a causal relationship between economic development and democratic survival (Przeworski et al., 2000; Acemoglu and Robinson, 2005). Similarly, favourable international conditions facilitate the emergence and consolidation of democratic regimes (Bunce, 2000). It is therefore necessary to support the people of the Arab 
streets and elites to enable this to happen, but to refrain from approaching the region through the lens of the conventional paradigm and instead respect the choices of the people of the region. ${ }^{27}$

Turkey, despite its flaws, as a promising case coalescing Islam and democracy, and the EU as the world's largest political economy bloc, giving priority to a normative foreign policy could create a renewed strategic vision to facilitate the transformation of the Arab region. Turkey and the EU should both appreciate this window of opportunity and seize the chance to influence the course for the remainder of the decade. If the EU continues to treat Turkey as simply a "crisis to be managed" and sticks to a short-term vision in the way it views this country, the EU will have missed an important opportunity and may remain a side-line spectator in the Middle East. On the other side of the coin, if Turkey insists on playing a solo-game, it may come across the expectations-capabilities gap that disappoints domestic audiences as well as the peoples of the region. Furthermore, Turkey's political economy stability may be jeopardized without a strong EU anchor. Therefore, instead of using one-sided rhetoric about exclusion, the parties have to start speaking in a constructive language that makes mutual detente possible. This would not just bring gains for both sides but also benefits to the world's most instable political basin.

\section{Notes}

1 Authors' interview with Muhammed Sarmini, a member of Syrian National Council, October 27, 2011, Ankara.

2 We would like to thank to Ahmet Davutoğlu (Minister of Foreign Affairs, Turkey), Ali Hussein Bakeer (USAK researcher, Jordan, Lebanon, Turkey), Ambassador Naci Koru (Deputy Minister of MFA, Turkey), Andrew Tabler (senior researcher, WINEP, USA), Eduard Soler i Lecha (political scientist, Spain), Erşad Hürmüzlü (Chief Advisor to the Turkish President Abdullah Gül, Turkey), Fatih Tayfur (international relations scholar, Turkey), Fuat Keyman (political scientist, Turkey), Graham Fuller (former vice-chair of the National Intelligence Council, USA), Heiko Schuß (expert on Middle Eastern economies, Germany), Hüseyin Bağcı (international relations scholar, Turkey), İbrahim Beyyumi Ghanem (political scientist, Egypt), İhsan Bal (political scientist, Turkey), Michael Hudson (political scientist, USA), Michael Lemmon (Ambassador R, USA), Michele Dunne (political scientist, USA), Misbah al-Ahdab (politician, Lebanon), Mouayed Alwindawi (political scientist, Iraq/ Jordan), Muhamed Ayoob (political scientist, USA), Muhammed Sarmini (member of Syrian National Council, Syria), Özdem Sanberk (Ambassador R, Turkey), Rabi al-Hafidh (Arab scholar, Iraq, UK), Ross Wilson (Ambassador R, USA), Sayyar al-Jamil (historian, Iraq/Qatar), Sedat Laçiner (political scientist, Turkey), Ted Piccone (senior researcher, Brookings Institute, USA), Vehbi Dinçerler (former state minister, Turkey), Yaşar Yakış (former Minister of Foreign Affairs, Turkey), Ziya Öniş (political economist, Turkey).

3 Authors' interview with senior Turkish diplomat Ambassador (R) Özdem Sanberk, November 23, 2011, Ankara.

4 Authors' interview with Sayyar al-Jamil, professor of Modern History and Contemporary Thought Senior-Advisor in Arab Centre for Research \& Political Studies, October 27, 2011, Ankara.

5 Author's personal observation in the Arab world enforces this argument. Also see Telhami (2011).

6 Dataset is retrieved from Republic of Turkey Ministry of Economy.

7 Particularly reform packages regarding the amendment of the constitution articles are very attractive for some circles in the Arab intelligentsia. Authors' interview with İbrahim Beyyumi Ghanem, a renowned Egyptian political scientist, June 23, 2011, İstanbul.

8 Authors' interview with İhsan Bal, one of the architects of the democratic initiative in Turkey regarding the Kurdish problem, September 28, Ankara.

9 Authors' interview with Misbah al-Ahdab, a Lebanese politician who is currently the Vice President of the Democratic Renewal Movement in Lebanon, October 27, 2011, Ankara. 
10 Ersel Aydinlı, a leading Turkish scholar stated his ideas on this issue in the conference on TurkishIsraeli relations organized by USAK on February 25, 2011, Ankara.

11 Authors' interview with Naci Koru, Deputy Undersecretariat of Ministry of Foreign Affairs, Turkey, December 12, 2011, Ankara.

12 Authors' interview with Turkish Foreign Minister Ahmet Davutoğlu, December 7, 2011. The Turkish version of the interview is published in Analist, No. 11, January 2012, pp. 6-15.

13 Authors' interview with Rabee al-Hafidh, Secretary General and Head of Arab-Turkish Unit, Forum of Muslim Thinkers, March 6, 2011, Ankara.

14 See note 9.

15 Authors' interview with Eduard Soler i Lecha, a Spanish political scientist mainly focusing on Mediterranean politics, October 27, 2011.

16 Without any exception, all of our interviewees underlined this point.

17 See note 3 .

18 One of the authors' conversations with Ambassador (R) Ross Wilson in Washington DC on December 19, 2011.

19 Authors' interview with Fuat Keyman, a leading Turkish foreign policy professor, April 24, 2011. Our interviewees from the Turkish Republic Ministry of Foreign Affairs also acknowledged this point (interviews are conducted between September 15 and December 15, 2011).

20 We would like to thank to Ambassador Naci Koru for providing us the relevant dataset.

21 See note 4.

22 Many of our Turkish interviewees seem to be optimistic on this issue. The Arabs, on the other hand, are quite sensitive. They in principle back trilateral cooperation yet they by no means accept any mechanisms to be "imposed upon them."

23 Authors' interview with Heiko Schuß, a German scholar from the University of Erlangen-Nürnberg focusing on economy of the Middle East, October 27, 2011, Ankara.

24 See note 3.

25 See note 12.

26 See note 15 .

27 One of the authors' conversations with Ambassador (R.) Michael Lemmon on December 16, 2011, Washington DC. Lemmon also stressed the importance of giving up the lens of "old school" while approaching the region.

\section{References}

Abramowitz, M. \& Barkey, H. J. (2009) Turkey's transformers: The AKP sees big, Foreign Affairs, 88(6), pp. 126-127.

Acemoglu, D. \& Robinson, J. (2005) Economic origins of dictatorship and democracy (Cambridge: Cambridge University Press).

Akgün, M. et al., (2011) The perception of Turkey in the Middle East 2010 (Istanbul: TESEV Publications 2011).

Altunışık, M. (2008) The possibilities and limits of Turkey's soft power in the Middle East, Insight Turkey,10(2), pp. 41-54.

Bayat, A. (2010) Life as politics: How ordinary people change the Middle East (Amsterdam: Amsterdam University Press).

Bellin, E. (2004) The robustness of authoritarianism in the Middle East in comparative exceptionalism perspective, Comparative Politics, 36(2), pp. 139-157.

Bunce, V. (2000) Comparative democratization, Comparative Political Studies, 33(6-7), pp. 703-734.

Dadush, U. \& Dunne, M. (2011) American and European responses: What is the bid idea, The Washington Quarterly, 34(4), pp. 131-146.

Dede, A. (2011) The Arab uprisings: Debating the Turkish model, Insight Turkey, 13(2), pp. $23-32$.

Dinçer, B. \& Aydemir, D. (2011) Transformation of identity in Turkish foreign policy, Journal of Turkish Weekly, September 27.

Frattini, F. (2011) A Marshall Plan for the Arab World, Project Syndicate, 26 May.

Füle, S. Speech on the recent events in North Africa Committee on Foreign Affairs (AFET), European Parliament, Brussels, 28 February 2011, SPEECH/11/130.

Grant, C. (2011) A new Neighbourhood Policy for the EU, CER Policy Brief. 
Hale, W. \& Özbudun, E. (2010) Islamism, democracy and liberalism in Turkey: The case of the AKP (New York: Routledge).

Huntington, S. P. (1991) The third wave: democratization in the late twentieth century (Oklahoma: University of Oklahoma Press).

Huysmans, J. (2000) The European Union and the securitization of migration, Journal of Common Market Studies, 38(5), pp. 751-777.

Keyman, F. \& İçduygu, A. (eds.) (2005) Citizenship in a global world: European questions and Turkish experiences (New York: Routledge).

Kirişci, K., Tocci, N. \& Walker, J. (2009) A neighbourhood discovered: Turkey's transatlantic value in the Middle East', Brussels Forum Paper Series.

Kutlay, M. (2011) Economy as the 'practical hand' of 'new Turkish Foreign Policy: A political economy explanation, Insight Turkey, 13(1), pp. 67-88.

Larrabee, F. S. (2010) Turkey's new geopolitics, Survival, 52(2), pp. 157-180.

Öniş, Z. \& Bakır, C. (2007) Turkey's political economy in the age of financial globalization: The significance of the EU anchor,' South European Society and Politics, 12(2), pp. 147-164.

Öniş, Z. \& Şenses, F. (eds.) (2009) Turkey and the global economy: Neo-liberal restructuring and integration in the post-crisis era (London: Routledge).

Öniş, Z. \& Yılmaz, Ş. (2009) Between Europeanization and Euro-Asianism: Foreign policy activism in Turkey during the AKP era, Turkish Studies, 10(1) pp. 7-24.

Pinto, A. C. \& Teixeira, N. S. (eds.) (2002) Southern Europe and the making of the European Union, 19451980s (New York: Columbia University Press).

Przeworski, A. \& et al. (2000) Democracy and development (Cambridge: Cambridge University Press).

Rettman, A. (2011) EU reacts to Arab spring with small-scale funding increase, EUobserver, 25 May.

Royo S. \& Manuel, C. P. (eds.) (2003) Spain and Portugal in the European Union (London: Frank Cass).

Sarıgil, Z. (2007) Europeanization as institutional change: The case of the Turkish military, Mediterranean Politics, 12(1), pp. 39-57.

Smith, K. E. (2005) Enlargement and European Order, in Christopher Hill and Michael Smith (eds.), International relations and the European Union (Oxford, Oxford University Press), pp. 271-291.

Stone, N. (2011) This Spring won't breed any more Turkeys, The Time, April 5.

Telhami, S. (2011) The 2011 Arab public opinion poll, conducted in October 2011.

Tocci, N. \& Cassarino, J. (2011) Rethinking the EU's Mediterranean policies post-1/11, IAI Working Papers, No.11|06.

Traynor, I. \& Willsher, K. (2011) Tunisian protests have caught Nicolas Sarkozy off guard, say opposition, TheGuardian, 17 January.

Ugur, M. (2010) Open-ended membership prospect and commitment credibility: Explaining the deadlock in EU-Turkey accession negotiations, Journal of Common Market Studies, 48(4), pp. 967-991. 